\section{Response to: 'Development and initial validation of diagnostic gene signatures for systemic lupus erythematosus' by Wang et al}

In their letter, Dr Wang and colleagues ${ }^{1}$ correctly remark that no novel molecular biomarkers were included in the European League Against Rheumatism/American College of Rheumatology (EULAR/ACR) 2019 classification criteria for systemic lupus erythematosus (SLE), although a variety of such markers were considered in the process, including the type I interferon signature. ${ }^{23}$ As cited by Wang et al, ${ }^{1}$ sufficient evidence and worldwide availability were of importance for inclusion into the list of classification criteria items.

Their approach presently is on the opposite side of the field, where early hypotheses are generated. Dr Wang and colleagues ${ }^{1}$ used robust rank aggregation for analysing multiple transcriptome data sets. Essentially all hits in this approach were interferon-regulated genes. Accordingly, the authors worked at enriching for genes of other modules, and over several steps arrived at a five-gene score, which was superior to any single gene in distinguishing SLE from healthy individuals.

This approach is interesting, and may in the end lead to markers relevant for diagnosis, as discussed by Dr Wang et al, ${ }^{1}$ but eventually also for classification. However, testing against various other autoimmune diseases, such as in the EULAR/ ACR SLE classification project, ${ }^{23}$ has not yet been shown. This in our view is relevant given, for example, the presence of an interferon signature also in other autoimmune diseases. ${ }^{4-6}$ Once this is successfully done, it will be interesting to see whether the combination of established criteria and such novel markers further improve classification.

\footnotetext{
Martin Aringer $\odot{ }^{1}{ }^{1}$ Karen Costenbader, ${ }^{2}$ Thomas Dörner $\bullet^{\circ},{ }^{3}$ Sindhu R Johnson ${ }^{4}$

'Divsison of Rheumatology, Department of Medicine III, University Medical Center and Faculty of Medicine Carl Gustav Carus, TU Dresden, Dresden, Germany 2Division of Rheumatology and Immunology, Department of Medicine, Brigham and Women's Hospital, Harvard Medical School, Boston, Massachusetts, USA ${ }^{3}$ Department of Rheumatology and Clinical Immunology, Charité Universitätsmedizin Berlin, Corporate member of Freie Universität Berlin, HumboldtUniversität zu Berlin, and Berlin Institute of Health, Berlin, Germany ${ }^{4}$ Division of Rheumatology, Department of Medicine, Toronto Western Hospital, Mount Sinai Hospital; Institute of Health Policy, Management and Evaluation, University of Toronto, Toronto, Ontario, Canada
}

Correspondence to Professor Martin Aringer, Internal Medicine III, Technical University of Dresden, Dresden 01069, Germany; martin.aringer@uniklinikum-dresden.de

Contributors All authors composed the response together and approved the submitted version.

Funding The authors have not declared a specific grant for this research from any funding agency in the public, commercial or not-for-profit sectors.

Competing interests None declared.

Patient consent for publication Not required.

Provenance and peer review Commissioned; internally peer reviewed.

(c) Author(s) (or their employer(s)) 2019. No commercial re-use. See rights and permissions. Published by BMJ.

\section{Check for updates}

To cite Aringer M, Costenbader K, Dörner T, et al. Ann Rheum Dis Epub ahead of print: [please include Day Month Year]. doi:10.1136/annrheumdis-2019-216807

Received 10 December 2019

Accepted 12 December 2019

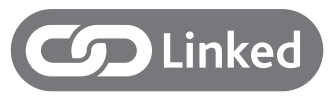

http://dx.doi.org/10.1136/annrheumdis-2019-216695

Ann Rheum Dis 2019;0:1. doi:10.1136/annrheumdis-2019-216807

ORCID iDs

Martin Aringer http://orcid.org/0000-0003-4471-8375

Thomas Dörner http://orcid.org/0000-0002-6478-7725

\section{REFERENCES}

1 Wang B, Chen S, Zheng Q, et al. Development and initial validation of diagnostic gene signatures for systemic lupus erythematosus. Ann Rheum Dis 2019:annrheumdis-2019-216695.

2 Aringer M, Costenbader K, Daikh D, et al. 2019 European League against Rheumatism/ American College of rheumatology classification criteria for systemic lupus erythematosus. Ann Rheum Dis 2019:78:1151-9.

3 Aringer M, Costenbader K, Daikh D, et al. 2019 European League against Rheumatism/ American College of rheumatology classification criteria for systemic lupus erythematosus. Arthritis Rheumatol 2019;71:1400-12.

4 Bodewes ILA, Björk A, Versnel MA, et al. Innate immunity and interferons in the pathogenesis of Sjögren's syndrome. Rheumatology 2019;11.

5 Gallay L, Mouchiroud G, Chazaud B. Interferon-signature in idiopathic inflammatory myopathies. Curr Opin Rheumatol 2019;31:634-42.

6 Barrat FJ, Crow MK, Ivashkiv LB. Interferon target-gene expression and epigenomic signatures in health and disease. Nat Immunol 2019;20:1574-83. 